\title{
CEO Turnover and IPO Performance
}

\author{
Guanyu Chen ${ }^{1}$ and Hengfeng $\mathrm{Xu}^{2^{*}}$ \\ ${ }^{1}$ Hangzhou Hump Supply Chain Limited \\ ${ }^{2}$ Lancaster University Management School
}

\begin{abstract}
Previous research presents extensive conclusive results regarding the association between firm performance and CEO turnover. However, the issue of CEO turnover is still rarely investigated with regard to the usefulness Initial Public Offerings (IPOs) performance in the topic of Chief Executives Officers (CEOs) turnovers. The principle objective of this study is to investigate *Correspondence to Author:

whether the likelihood of the CEOs turnover is inversely correlatGuanyu Chen ed with the IPO performance of the firm. This study is conducted by employing the U.S. sample data consists of 462 firms including 173 CEO turnover events within 5 years after the IPO offering during the period between 2003 and 2013, and it is mainly conHangzhou Hump Supply Chain Limited, Room 497, Shixiang Road, Gongshu District, Hangzhou City, Zhejiang Province, China.

cluded that CEO turnover matters with respect to firm IPO per-

How to cite this article:

formance, however, only for IPO long-term performance, rather than short-term performance.

Guanyu Chen and Hengfeng Xu. CEO Turnover and IPO Performance. Global journal of Economics and Business Administration, 2020, 5:34.

\section{eScîPub}

eSciPub LLC, Houston, TX USA.

Website: http://escipub.com/
\end{abstract}




\section{Introduction}

Previous evidences suggest that IPO companies, although highly underpriced, they tend to underperform in the long run. Ritter (1991) find that IPO underperformed their market benchmarks approximately negative $34.5 \%$ for three years holding period by investigating 1526 IPOs that went public in U.S during the period 1975-84. Similarly, Ritter and Welch (2002) contend that three-year holding-period returns for an investor, purchasing at the offer price, would underperform the market weighted CRSP index dramatically by investigating 6249 IPOs occurred from $1980-2001$.

Going deeper of the IPO performance in U.S., this paper aims to explore the determinants of CEO dismissals for the sake of investigating the link between IPO performance and CEO departures by employing sample consists of 462 U.S. listed firms, furthermore, achieve a better and clearer insight into the CEO turnover procedure in U.S. firms. Besides, this study would summarize and conclude the research outcome to prove the correlation between CEO turnover and firm IPO performance as well as the CEO and firm characteristics that would be the reasons for CEO turnover. Hence, this paper mainly expects to contribute to IPO literature by bringing out a comparable innovative and comprehensive empirical analysis of how IPO performance influences the decisions to CEO turnover during the period between 2003 and 2013 in U.S.

Employing and dismissing a CEO may be one of the most crucial jobs of a firm board. There is a large literature in the area of finance and accounting interpreting how CEO dismissals takes place, as those earlier articles documented by Coughlan and Schmidt (1985), Warner, Watts and Wruck (1988) and Weisbach (1988). They indicate that the threat of dismissal is an implicit stimulus to encourage CEO to give a supreme effort. Furthermore, since the testament to its significance, the topic with respect to CEO departures was expected to draw great interest of large number of scholars to explore on it, including recent research achievement accomplished by Fisman, Khurana, Rhodes-Kropf and Yim (2013), Jenter and Kanaan (2015) and Taylor (2010). However, the picture of firms' IPO abnormal performance is still unclear with regard to their relationship with CEO dismissals, there is no previous comparable research exists for U.S. listed firms. Perhaps more importantly, U.S. is an ideal case for a study of IPO performance that determines CEO turnover is particularly important due to the IPO activity lively in U.S listed firms, which it can reliable capture for firm performance' core aspect.

Specially, this research's objectives can be addressed in the following context: Firstly, to critically evaluate relevant theoretically literature with regard to the IPO long-term performance and short-term performance in order to generalize conceptual framework that will assist to understand the IPO performance in U.S. Secondly, to critically evaluate relevant theoretically literature with respect to CEO dismissals for the sake of developing a conceptual framework which it will contribute to understand CEO departures in U.S. Thirdly, to identify and investigate the CEO and firm characteristics which influence on CEO turnover procedure in U.S. listed firms. Finally, to examine the association between CEO dismissals and company IPO performance in U.S. public firms, which it is the centrality objective of this research study.

In order to accomplish the aim and objectives of this paper, there is variety of questions needs to be defined for the current research. Firstly, what are the factors that influence on CEO dismissals procedure in U.S listed firms? Secondly, what is association between company IPO performance and CEO departures in U.S. public firms? Lastly, what is the managerial implication of CEO turnover regarding the IPO performance in U.S. understood by CEO replaced.

This paper can contribute to bring an insight and review of the previous researches with regard to exploring the reasons for CEO turnovers in an innovative area that concentrates on IPO performance. Turning to empirical analysis of this study, it employs buy-and-hold stock return for 
three years holding period as the measure of IPO long-term performance. This paper mainly expects to observe the decision to turnover is negatively related to firms' IPO long-term abnormal performance. And as the primary prediction of this study, in concept, it would be consistent with the extensive literature regarding the association between $\mathrm{CEO}$ departures and poor firm performance, such as the studies of Fee and Hadlock (2004) and Faleye (2007).

Furthermore, for IPO short-term performance that proxied by initial return on the first trading day, this paper predicts that the decision to turnover is insignificantly correlated with IPO shortterm performance. It attempts to be in line with Chang and Wong (2009) who indicate that CEO dismissals has no relationship with the firms that achieves the profitability. And it is believed that it could be explained by Ritter and Welch (2002) and Lowry, Officer and Schwert (2010), who point out that the volatility of IPO initial return fluctuates significantly over time. Consequently, CEO is not directly responsible for such extraordinary return with dramatically changes over time in the short run.

Besides, it considers the accounting performance that captured by return on asset in the IPO year Barber and Lyon (1996) on turnover decisions, and it predicts that there is a negative association between ROA in the IPO year and CEO turnover afterwards. Additionally, this study includes controls for other hypothesized CEO and firm-level determinants of CEO replaced, including CEO founder status, age, tenure, education, gender, as well as firm size and age. The empirical findings of this study would be beneficial for helping shareholders and boards formulate their opinion about CEO performance, and more broadly, provide a frame of reference for their decisions to make retention or termination of a CEO position.

The remaining part of the paper is organized as follows. section 2 reviews the related literature in the area of IPO short term and long term performance and discusses how prior firm performance and CEO (firm) characteristics drives
CEO turnover, and then sets up the hypothesis development. Section 3 describes the data and the final sample, and introduces the methodology of this research study in details that will contribute to examine the hypotheses, afterwards, interprets the reasons for selecting the methodology. Section 4 presents the regression results of investigating the relationship between IPO performances (as well as other CEO or firm characteristics) and CEO turnover, and then makes empirical results discussion. Finally, Section 5 reviews the main findings, reflects the managerial implications, summarizes the limitations of this study, and shows the recommendations for future study.

\section{Hypothesis Development}

CEO is normally regarded as a 'scapegoat' for the firm's poor performance and has been explained by many research papers. The scapegoat hypothesis was created and developed based on the agency models of Hölmstrom (1979), Shavell (1979) and Mirrlees (1976). Furtado and Karan (1990) investigate chosen empirical research concentrate on various perspectives of turnover, factors that lead to the change, the aftermath of changes as well as impacts of the changes on top executive management. They present strong and adequate evidence to support that poor performance cannot be endured by board of directors. Additionally, they call for further studies to ensure whether turnover is only scapegoating, in other words, whether CEOs are in fact being had directly responsible for poorly firm performance. CEOs leave their current positions can be due to various reasons, an extensive literature presents that the probability of CEO turnover is inversely correlated to firm performance, as the conclusion drawn by Murphy and Zimmerman (1993). This hypothesis assumes based on company performance reflecting information with regard to a CEO's capability to create wealth for companies 'shareholders. A CEO is terminated or replaced when the performance of firm is weak (e.g. receive negative stock returns, as well as earnings declined), since the company's owners deduce that 
there is no efficient CEO within the firm that can guide the implementation of the appropriate policies and strategies for contributing to shareholders' wealth Dikolli, Mayew and Nanda (2014).

Pagano, Panetta, Zingales and Luigi (1998) contend a larger CEO turnover than normal in the three years following a firm IPO. It is conceptually consistent with the evidence that contemporaneous contended by Warner, Watts and Wruck (1988) and Weisbach (1988), who document that boards of directors are likely to punish weak performance by means of replacing CEOs. Furthermore, Depperu, Fabrizi and Ghezzi (2013) examine the dynamic of CEO turnover, both in before and after the non-financial Italian firm IPO during the period between 2000 and 2008. They indicate that CEO turnover can be drived by many factors regarding firm, individual career and characteristics. Their empirical analysis results represent that compared with the pre-IPO period; the CEO turnover rate will be higher, furthermore, the probability of CEO turnover is highly associated with the firm financial performance during the post-IPO period. The centrality of the CEO is represented in the empirical literature connecting CEO turnover to poor company performance. The principal prediction of this study is: If the firms do not perform well after the offering, the CEO is likely to be replaced.

Warner, Watts and Wruck (1988) test the US sample data, including 269 companies that listed on the New York as well as American Stock exchanges during the period from 1962 to 1978, in order to investigate whether the management turnover is associated with stock returns or not, and they find that there is a significant negative relationship between those two variables. Furthermore, they indicate that the empirical result they provided has very little correlation for companies with intermediate returns, however, is mostly impelled by the companies with excessively low stock returns.

Gibbons and Murphy (1990) provide similarly argument, they document that CEO turnover can be significant negatively influenced by the company's own stock returns, while can be positively affected by the market return. Their empirical results also indicate that CEOs are disciplined according to their own poor performance, however, not related to the economy-wide poor performance. During the same period, Jensen and Murphy (1990) state that their empirical analysis indicating CEOs tend to depart from their companies after bad performance period rather than good years and hence are punished by the menace of termination. It is also consistent with Hölmstrom (1979). In the following, Denis and Denis (1995) show empirical evidence that forced CEOs changes are induced by large and dramatically decrease in company performance, employing performance on share price, market-adjusted return, as well as ratios of operating income relative to total assets. It is also noted that the changes on CEOs is followed apparently progress in the performance.

Brickley (2003) assert that accounting returns and stock returns cannot be used to interpret most proportion of the variation in CEO turnover, indicating the company performance has very little ability to interpret the cross -sectional and time-series variations in CEO turnovers, although those companies with accounting returns are supposed to reflect relatively sufficient information with regard to managerial performance. However, Huson, Malatesta and Parrino (2004) analyse the association between CEO turnover and firm financial performance. They show that companies' financial performance tends to get worse before top management turnover. Other studies also provide similar argument, as Adams and Mansi (2009) also indicate that a turnover can be produced by poor prior performance, CEOs are held responsible for company weak performance. Furthermore, Chang and Wong (2009) investigate whether CEO turnover is correlated to the performance of listed companies, they document that there is a negative association between the degree of likelihood of turnover and CEO replacement when companies suffering from financial losses, however, they indicate that there is no correlation for those companies 
making profits. Therefore, shareholders have mightily incentives to punish CEOs in reference to the financial performance of the company.

Additionally, Dikolli, Mayew and Nanda (2014) examine the listed US firm sample data during the period between year 1996 and year 2005 and they contend that the probability of CEO turnover is predicted monotonically growing in the degree of negative financial performance which employ stock returns and ROA as measures of prior performance. It is consistent with Kato and Long (2006) who document the evidence to support that CEO replaced is inversely correlated to the accounting performance as well as stock market.

Given the discussions above, we propose the following hypothesis:

There is a negative association between CEO turnover and the firm's IPO performance.

\section{Data and Methodology}

\subsection{Data Sourcing and Sample Data For- mation}

The data implemented to carry out the empirical experiment tests are collected independently by the author of this study. The data of this study comes from several sources. Financial stock return that will be employed to measure IPO performance are collected from Centre for Research in Securities Prices (CRSP), and return on asset in the IPO year will be adopted to assess accounting performance are collected from COMPUSTAT. This study employs a unique hand-collected dataset of CEO information such as CEO tenure, CEO education, CEO age, CEO gender, which they are available in Boardex. The relevant information of CEO turnover is collected from Audit Analytics. Company founding years are collected from the Field-Ritter dataset. The industry classification is based on 2-Digit standard industrial classification (SIC) code.

The initial sample has 919 firms spanning the years 2003 to 2013. Final data sample is determined after taking the data availability into consideration. After imposing data requirements for firms buy-and hold stock return for three years holding period following the IPO offering, initial return and control variables, the sample is reduced to 462 firm-year observations, including 173 CEO turnover events within the 5 years after the IPO issuing. Additional data restrictions will be shown in subsequent cross-sectional analysis; consequently, the number of observations varies across tests. Based on the sample data provided, there is a highly organized methodology consisting of statistical approaches to examine hypotheses for carrying out replication and generalisation of this research.

\subsection{The Rationale for Research Method}

It is crucial to design research methodology for the sake of investigating the hypotheses; the quantitative methodology can be regarded as an appropriate approach of the current research. In order or purse the research objectives of this study, it is important to understand how to measure the CEO turnover as well as identify the determinants that can influence the CEO replaced in U.S. listed firms. Warner, Watts and Wruck (1988) document a robust turnover correlation between company performance and the likelihood of forced dismissal. However, in this study, the measure of turnover does not differentiate between involuntary turnover and voluntary turnover, which classified as board initiated, or receive a more attractive position provided by other companies or retirement. Since Denis and Denis (1995) indicate that companies do not in general specifically announce whether or not a CEO has been replaced or hired, although under the situation of CEO was dismissed. And consequently, this research neglects the classification of CEO turnover in U.S. listed firms.

Besides, the sake of examining the reasons for CEOs dismissal, it is necessary to estimate the research models. Historically, there are a great number of scholars contend that logistic regression models can be employed to investigate the causes of CEO turnover, as documented by Coughlan and Schmidt (1985) and Goyal and Park (2002). Furthermore, there are also amount of typical literature specifically suggest that using logistic regression models can be regarded 
as an appropriate approach in order to investigate the determinants of CEO replaced, as released by Chang and Wong (2009) and Firth, Fung and Rui (2006). Additionally, according to Hosmer Jr and Lemeshow (2004), they contend that a logistic regression model is a method to tests the cases in which there are over two possible values for the dependent variable, and if the independent variables are specifically categorical variables, it is a better approach to adopt logistic regression when making data empirical analysis. In this research, CEO turnover is the outcome variable and it is observed whether or not enterprises witnessed dismissals in CEO position following the IPO issuing over the observation period between 2003 and 2013. Hence, the response variable can facilitate to treat as a category which describes the position of CEO changes following the IPO or no changes. The logistic models are employed in this research for the purpose of investigating the reasons for CEO turnovers in U.S. listed firms.

\subsection{Logistic Regression Implementation}

As interpreted above, logistic regression method has been selected to investigate the objectives of this paper, hence, this section attempts to design and implement logistic models for the study, which they are in line with the prior literature Kato and Long (2006) and Chang and Wong (2009). Since the response variable is dichotomous (dummy) variable in order to classify whether or not CEO turnover following the IPO, the basic logistic model can be expressed in the following way;

CEOturnover ${ }_{i}=\beta_{0}+\beta_{1} X_{1 i}+\beta_{1} X_{2 i}+\beta_{3} X_{3 i}+\ldots .+\beta_{n} X_{i}$ $+\varepsilon$

In this basic model, $X_{1}, X_{2}, X_{3}, \ldots, X_{n}$ describe for independent variable as well as control variables which they are defined in Table 3 , and they will be further explained in the following section. In the meanwhile, $\beta_{0}, \beta_{1}, \beta_{2}, \beta_{3}, \ldots, \beta_{n}$ reflect the coefficients that need to be evaluated with regard to the independent variable as well as control variables. Besides, $\varepsilon$ means the disturbance term. In addition, $l$ represents the $l^{\text {th }}$ of observation, with $=1, \ldots, N$.

\subsection{Explanations for Variable Definition and Measurement}

This section attempts to make definitions and measurement of dependent variables and independent variables as well as control variables for the sake of employing and investigating the research logistic regression models. For the purpose of proving the appropriateness and reasonable of the selected approach, the variables definitions and their measurement will be introduced in consistent with the previous concerned literature.

\subsubsection{Dependent Variable}

CEO turnover is the primary outcome variable in the logistic regression models. As explained in the above section 3.2, it is important to deliberate the construction of the response variable. According to the points mentioned in section 3.2, this research considers to exclude the classification of CEO turnover between voluntary and involuntary. The methodology in this study is conservative although some researches distinguished the two types of CEO departures. According to Firth, Fung and Rui (2006), they point out that there are only a small proportion of the cases that can be classified as forced CEO dismissals. Kato and Long (2006) attempt to support this view contemporaneous and they neglect the differences between CEO voluntary turnover and involuntary replaced. Hence, a CEO turnover is assessed by changes in CEO positions following the IPO issued in U.S. listed firms. And consequently, the dependent variable of the regression model is dichotomous variable indicating CEO turnover or not following the IPO issued, with the notion 1 for turnover and 0 for others. It is an appropriate method to conduct the logistic regression models for the sake of evaluating the determinants of CEO dismissals.

\subsubsection{Independent Variables}

IPO long-term performance \& IPO short-term performance

It is important to select a measure, which it could reliable capture for company performance' core 
aspects. Main variable of interest in this study is IPO long-term stock performance, which is proxied by three-year post-issue buy-and-hold stock returns ('BHAR3years'). Barber and Lyon (1997) argue that compared with CAR (e.g. Ritter (1991)), BHAR (e.g. Loughran and Ritter (1995); Ritter and Welch (2002); Brau, Couch and Sutton (2012)) can be regard as a more appropriate approach for measuring the IPOs long-run performance. Besides, Lyon, Barber and Tsai (1999) asset that since BHAR are considered to have a better performance when it used to evaluate the investors' actual buy-and-hold experience, hence, BHARs are more prominent. And for those reasons, the empirical results computed by the methodology of BHAR will be preferential. The second measure is IPO short-term performance, which is proxied by IPO initial return on the first trading day.

\section{Accounting performance}

The additional measure will be the focus of accounting performance that captured by return on asset in the IPO year, as employed in the studies of Harrison, Torres and Kukalis (1988) and Virany, Tushman and Romanelli (1985). Besides, Barber and Lyon (1996) point out that accounting measure of firms' performance often has advantage of measuring the long term performance. In addition, according to Hermalin and Weisbach (1988), they contend that accounting performance measure can be regarded as a favourable predictor of CEO turnover since earnings report the performance of current management.

\subsubsection{Control Variables}

All CEO-specific and firm-specific explanatory variables interpreted in Chapter 2 that are supposed to be correlated with the reasons for CEO turnover are controlled in the logit regression models. For CEO characteristics, CEO founder is a dummy variable that describes whether the CEO is also one of the firm's founders. Consistent with the management literature Finkelstein (1992), this study considers examining whether CEOs who are also founders can be more influential, and consequently to test whether the founder status can contribute to the CEO turnover.

CEO age is measured by the logarithm of this variable. Consistent with Barro and Barro (1990) and Brickley (2003), who indicate that this study controls this variable and considers investigating whether old CEOs tend to be replaced following the IPO issuing. CEO tenure can reflect managerial entrenchment power as documented by Dikolli, Mayew and Nanda (2014), they also indicate that there is a positive association between longer CEO tenure and poor governance structures; furthermore, they highlight the significance of tenure in influencing the correlation between firm performance and CEO dismissals. Hence, the effect of CEO tenure is deliberated in this research. And this variable is assessed by the number of years the CEO has been in the office.

This study following Bertrand and Schoar (2003), who consider a dummy variable for whether or not the CEO has a MBA degree, with the notion 1 for having a MBA degree and 0 otherwise. This paper designs a dummy variable to describe CEOs' gender in regression model for the sake of controlling gender bias, with the notion 1 for female and 0 otherwise. Consistent with Lyness and Judiesch (2001) and Schuert, Brown, Gysler and Brachinger (1999), who contend female and male CEOs have different actions when make decisions, consequently, may lead to the different effects on company performance that may influence turnover rate.

For firm characteristics, firm size is the natural logarithm of the firm at the end of IPO year $(L n M V t)$ in this paper, which it is consistent with Loughran and Ritter (1995). Besides, firm age shall be included and controlled in the regression model; the idea is that stock return of older companies tends to be less volatile. The variable of 'LogAge' describes the logarithm of firm age; it measures the age of the firm in years at the time of IPO.

\subsection{Empirical Analysis Procedure}


After making the definitions of the variables, this section attempts to introduce the empirical analysis procedure of the research for the purpose of investigating the research questions with respect to the determinants of CEO replaced. First of all, the logit regression models that will be employed to examine the hypotheses are presented. And then, the methods used to describe and analyse the collected sample data will be interpreted in the remainder of this section.

\subsubsection{Logit Regression Models Method}

Firstly, employ CEO change within 5 years after the IPO ('CEOchwithin5) to test whether the IPO performance affects the likelihood of CEO turnover within 5 years after the offering. This dependent variable equals to one if CEO is replaced within 5 years following the IPOs, and 0 otherwise. This test will be examined by the equation in the following. It is industry-adjusted, with industry classification according to two-digit SIC codes, besides, the year effect is also included to consider the time trend.

$C E O_{\text {chwithin5 }}=\beta_{0}+\beta_{1}$ PostIPO $O_{B H A R 3 y e a r s}+\beta_{2} C E O_{\text {Founder }}+\beta_{3} M V_{t}+\beta_{4} \log$ Age $+\beta_{5} R O A_{t}+\beta_{6} \log C E O_{\text {Age }}$ $+\beta_{7} C E_{\text {Femal }}+\beta_{8} C E O_{\text {Tenure }}+\beta_{9} C E O_{M B A}$ Industrydummies + Yeardummies $+\varepsilon$

Then, replace 'CEOchwithin5 with'CE- one if CEO dismissals within 3 years after the Ochwithin3', to test whether the IPO perfor- IPO, and equals to zero otherwise. This test will mance affects the probability of CEO turnover be investigated by the way in the following. within 3 years after the IPO offering. It equals to

$C E O_{\text {chwithin3 }}=\beta_{0}+\beta_{1}$ PostIPO $_{\text {BHAR3years }}+\beta_{2} C E O_{\text {Founder }}+\beta_{3} \ln M V_{t}+\beta_{4} \log A g e+\beta_{5} R O A_{t}+\beta_{6} \log C E O_{\text {Age }}$ $+\beta_{7} C E_{\text {Female }}+\beta_{8} C E O_{\text {Tenure }}+\beta_{9} C E O_{M B A+}$ Industrydummies + Yeardummies $+\varepsilon$

Secondly, replace three-year post-issue buyand-hold stock returns ('BHAR3years') with Log initial return ('LogIR'), initial return, that is, the stock return on the $1^{\text {st }}$ trading day, to test other type of IPO performance, which is IPO underpricing in order to examine how it affects CEO turnover within 5 years after the IPO offering. This test is represented in the following model.

$C E O_{\text {chwithin5years }}=\beta_{0}+\beta_{1} \log I R+\beta_{2} C E O_{\text {Founder }}+\beta_{3} \ln M V_{t}+\beta_{4} \log A g e+\beta_{5} R O A_{t}+\beta_{6} \log C E O_{\text {Age }}+\beta_{7} C E_{\text {Female }}$ $+\beta_{8} C E O_{\text {Tenure }}+\beta_{9} C E O_{M B A+}$ Industrydummies + Yeardummies $+\varepsilon$

Next, for firm IPO short-term performance, whether it will have impact on the CEO turnover after 1 year following the IPO launching will be explored by the following equation. 'CEOch1' equals to one if CEO departures after one year following the IPO, and equals to zero otherwise.

$C E O_{\text {ch } 1}=\beta_{0}+\beta_{1} \log I R+\beta_{2} C E O_{\text {Founder }}+\beta_{3} \ln M V_{t}+\beta_{4} \log A g e+\beta_{5} R O A_{t}+\beta_{6} \log C E O_{\text {Age }}+\beta_{7} C E_{\text {Female }}+\beta_{8} C E-$ $O_{\text {Tenure }}+\beta_{9} C E O_{M B A}$ Industrydummies + Yeardummies $+\varepsilon$

Additionally, replace three-year post-issue buyand-hold stock returns ('BHAR3years') with the measure of firm accounting profitability, that is, the average net income divide by total asset in the IPO year (ROAt) . 'CEOch2' equals to one if CEO departures after two years following the IPO, and equals to zero otherwise. This additionally test is expressed in the following. 
$C E O_{\text {ch } 1}=\beta_{0}+\beta_{1} R O A_{t}+\beta_{2} C E O_{\text {Founder }}+\beta_{3} \ln M V_{t}+\beta_{4} \log A g e+\beta_{5} \log C E O_{A g}+\beta_{6} C E_{\text {Female }}+\beta_{7} C E O_{\text {Tenure }}+\beta_{8}$ $C E O_{M B A+}$ Industrydummies + Yeardummies $+\varepsilon$

\section{Empirical Result Analysis Methods}

This section will briefly introduce the analysis of empirical results employed in the following chapters. As an experimental research, there are a great number of statistical techniques that can be used to conduct. To begin with descriptive statistical indicators, for instance, the mean, and standard deviation, minimum and maximum of all variables shall be interpreted in order to intuitionistic analysis the collected sample data. Besides, this study attempts to adopt Pearson correlation which contributes to highlight the linear correlation between two variables. Therefore, this test is simply used to investigate the association between variables defined in the current research.
Furthermore, previous researches with regard to CEO changes recommend employing t-statistics as well as $z$-statistics to examine the turnover rates within observed companies, such as the empirical methods conducted by DeFond and Park (1999). They suggest that t-statistics is employed in t-tests for comparing the means, while z-statistics is used in Wilcoxon rank-sum tests for comparing the medians (central tendency) among two different groups. Hence, the current research study will follow the recommendations from previous literature, however, is using unified $p$-values which it is exactly similar with the usefulness of t-statistics and z-statistics to analyse to test the difference between mean (median) among different groups.

Table 1 Description of turnover years The table report sample frequencies of years of CEO turnovers. The whole sample consists of 462 firms and 173 CEO turnover events occurred within 5 years after the IPO during the period between 2003 and 2013

\begin{tabular}{lllllll}
\hline Year & \multicolumn{2}{c}{ All IPOS } & \multicolumn{2}{c}{ CEO unchanged IPOs } & \multicolumn{2}{c}{ CEO changed IPOs } \\
\hline $\mathbf{2 0 0 3}$ & $\mathbf{N}$ & $\%$ & $\boldsymbol{N}$ & $\%$ & $\boldsymbol{N}$ & $\%$ \\
$\mathbf{2 0 0 4}$ & 64 & 4.33 & 9 & 3.11 & 11 & 6.36 \\
$\mathbf{2 0 0 5}$ & 54 & 13.85 & 33 & 11.42 & 31 & $\mathbf{1 7 . 9 2}$ \\
$\mathbf{2 0 0 6}$ & 62 & 11.69 & 36 & 12.46 & 18 & 10.40 \\
$\mathbf{2 0 0 7}$ & 61 & 13.42 & 36 & 12.46 & 26 & $\mathbf{1 5 . 0 3}$ \\
$\mathbf{2 0 0 8}$ & 8 & 13.20 & 34 & 11.76 & 27 & $\mathbf{1 5 . 6 1}$ \\
$\mathbf{2 0 0 9}$ & 19 & 1.73 & 4 & 1.38 & 4 & 2.31 \\
$\mathbf{2 0 1 0}$ & 31 & 4.11 & 9 & 3.11 & 10 & 5.78 \\
$\mathbf{2 0 1 1}$ & 34 & 6.71 & 20 & 6.92 & 11 & 6.36 \\
$\mathbf{2 0 1 2}$ & 50 & 7.36 & 18 & 6.23 & 16 & 9.25 \\
$\mathbf{2 0 1 3}$ & 59 & 10.82 & 40 & 13.84 & 10 & 5.78 \\
Total & 462 & 12.77 & 50 & 17.30 & 9 & 5.20 \\
\hline
\end{tabular}

Additionally, it is believed that logistic regression models in this study can bring out the strongest analysis. Following the implementations of regressing CEO turnover with the dependent 
variables as well as control variables, the hypothesis can be examined. And the coefficients will provide the direction of the association between CEO turnover and its determinants, and $\mathrm{t}$ statistics and $p$-values will be presented to make respond to whether accept or reject the null hypotheses set up in the section 2.7. The empirical results also will be discussed in accordance with the empirical results conducted by previous scholars and researchers regarding CEO turnover.

\section{Empirical Results Analysis}

\subsection{Descriptive Statistics for dependent and explanatory variables}

Table 1 illustrates the sample frequencies of CEO turnover years. CEO turnover after the IPO issuing occurred most frequently in years 2004, 2006 and 2007, less frequently in years 2008 and 2009. For those years with high frequency of CEO turnover within 5 years following the IPO, this phenomenon is supposed to indicate that the likelihood of higher CEO turnover, due to the IPO abnormal performance. And it is not surprising for those years with lower frequency of CEO turnover, the global financial crisis of 2008-2009 is the sign that the economic recession has bottomed out, and scholars refer to such phenomenon as the existence of cold IPO market as documented by lbbotson (1975) and Ritter (1984), few growth companies concentrate on going public during this period as the accompanying stock market descend would in line with cold period in the IPO marketplace. Therefore, it seems to illustrate that the more observations of firms that go public are undertaken in one of years during the period between 2003 and 2013, the more CEO replaced within 5 years following the IPO are observed in that specific year.

Table 2 Description of turnover firms 'industries Sample frequencies of industries of CEO turnover companies can be observed from tables 2. The whole sample consists of 462 firms, and 173 CEO turnover events occurred within 5 years after the IPO during the period between 2003 and 2013. Industries are classified employing criteria of the 2-Digit SIC standard industrial classification.

\begin{tabular}{|c|c|c|c|c|c|c|c|}
\hline \multirow[t]{2}{*}{ Industry name } & \multirow[t]{2}{*}{ SIC codes } & \multicolumn{2}{|c|}{ All IPOS } & \multicolumn{2}{|c|}{ CEO unchanged IPOs } & \multicolumn{2}{|c|}{ CEO changed IPOs } \\
\hline & & $\mathrm{N}$ & $\%$ & $\mathrm{~N}$ & $\%$ & $\mathrm{~N}$ & $\%$ \\
\hline Oil \& Gas Extraction & 13 & 17 & 3.68 & 14 & 4.84 & 3 & 1.73 \\
\hline Chemical \& Allied Product & 28 & 73 & 15.80 & 48 & 16.61 & 25 & 14.45 \\
\hline $\begin{array}{l}\text { Industrial Machinery \& Equip- } \\
\text { ment }\end{array}$ & 35 & 20 & 4.33 & 12 & 4.15 & 8 & 4.62 \\
\hline $\begin{array}{l}\text { Electronic \& Other Electric } \\
\text { Equipment }\end{array}$ & 36 & 45 & 9.74 & 28 & 9.69 & 17 & 9.83 \\
\hline Instruments \&Related Products & 38 & 35 & 7.58 & 24 & 8.30 & 11 & 6.36 \\
\hline Transportation \& Public Utilities & $42,44-49$ & 29 & 6.28 & 23 & 7.96 & 8 & 4.62 \\
\hline Wholesale and Retail Trading & $50-52,54,56-59$ & 47 & 10.17 & 43 & 14.88 & 22 & 12.72 \\
\hline Business Services & 73 & 118 & 25.54 & 81 & 28.03 & 37 & 21.39 \\
\hline All Others & $\begin{array}{l}12,14,17,20 \\
23-27,29-31,33 \\
34,37,70,72,75 \\
78-80,82,83,87\end{array}$ & 78 & 16.88 & 16 & 5.54 & 42 & 24.28 \\
\hline Total & & 462 & 100 & 289 & 100 & 173 & 100 \\
\hline
\end{tabular}


Table 3 Variables Definition

\begin{tabular}{|c|c|}
\hline Variables & Definition \\
\hline \multicolumn{2}{|c|}{ Dependent Variables } \\
\hline CEOchwithin5 & $\begin{array}{l}\text { CEO turnover within } 5 \text { years following the IPO, it equals one if CEO is replaced within } 5 \text { years after the IPO, } \\
\text { and } 0 \text { otherwise }\end{array}$ \\
\hline CEOchwithin3 & $\begin{array}{l}\text { CEO turnover within } 3 \text { years following the IPO, it equals one if CEO is replaced within } 3 \text { years after the IPO, } \\
\text { and } 0 \text { otherwise }\end{array}$ \\
\hline CEOch1 & CEO turnover 1 year following the IPO, it equals one if CEO is replaced 1 year after the IPO, and 0 otherwise \\
\hline CEOch2 & $\begin{array}{l}\text { CEO turnover } 2 \text { years following the IPO, it equals one if CEO is replaced } 2 \text { years after the IPO, and } 0 \\
\text { otherwise }\end{array}$ \\
\hline CEOch3 & $\begin{array}{l}\text { CEO turnover } 3 \text { years following the IPO, it equals one if CEO is replaced } 3 \text { years after the IPO, and } 0 \\
\text { otherwise }\end{array}$ \\
\hline \multicolumn{2}{|c|}{ Independent Variables } \\
\hline FirmBHAR3years & Post-IPO buy-and-hold stock return for three years holding period \\
\hline LogIR & The logarithm of initial returns, that is, the stock return on the 1st trading day after the IPO launched \\
\hline ROAt & $\begin{array}{l}\text { It defined as return on asset (ROA in the IPO year), which is measured as pre-tax operating income (net } \\
\text { income) divided by total assets. }\end{array}$ \\
\hline LnMVt & The logarithm natural of the market value (firm size) at the end of IPO year. \\
\hline LogAge & The logarithm of firm age, it measures the age of the firm in years at the time of IPO \\
\hline LogCEOage & The logarithm of CEO age \\
\hline CEOtenure & The number of years the CEO has been in the office (time working as CEO recorded in the firm). \\
\hline Founder & Dummy variable, it equals one if the CEO is also the firm founder, and zero otherwise. \\
\hline Female & Dummy variable, it equals one if CEO is female, and zero otherwise. \\
\hline CEOmba & Dummy variable, it equals one if the CEO has an MBA degree, and zero otherwise. \\
\hline
\end{tabular}

Table 2 describes sample frequencies of industries. In this sample, companies in business services and chemical \& Allied product are most frequently experience CEO turnovers within 5 years following the IPO issuing. Table 2 reports that $21.39 \%$ of the companies are in business service that occupied the largest proportion and $14.45 \%$ of the companies are in chemical \& Allied product industry in the following.

Table 3 records the definitions of independent variables. Table 4 documents the correlation matrix for the covariates. The most obviously correlation coefficient is found between LnMVt (firm size) and IPO initial return ( $r=.380)$, indicating that larger companies are likely to have higher IPO initial return. Besides, larger companies tend to have larger return on asset of IPO firms as shown in the correlation coefficient shown between LnMVt (firm size) and ROAt $(r=.277)$. The relatively low correlation among the covariates in Table 4 can help avoid the issue of multi-collinearity occur in this study analysis.

Table 5 reports descriptive statistics for the sample. This table shows the IPO performance, firm characteristics and CEO characteristics for the completed CEO turnover sample (462 firms), the sample with CEO turnover (173 firms), and the sample without CEO turnover (289 firms). For each sample in the whole table, the mean, standard deviation, Minimum (Min) and Maximum (Max) of all variables are calculated. It is interesting to note that CEO tenure in U.S. is longer than CEOs in China as reported by (Kato and Long (2006), CEO stayed with the company roughly 5.4 years, on average in U.S listed enterprises.). In panel B, it can be seen clearly that non-turnover sample has a larger mean (0.23) and median (-0.12) IPO firm buy-and-hold stock return for three years holding period that proxy for the main interest variable of this study, compared with the mean $(-0.23)$ and median $(-0.47)$ nal-of-economics-and-business-administration/ 
in CEO-turnover sample within 5 years following the IPO issuing.

\subsection{Mean Test and Wilcox Ranksum Test Re- sult}

Table 6 shows the results of mean test (t test) and Wilcoxon ranksum tests for the sample of CEO changes within 5 years following the IPO, CEO changes within 3 years following the IPO, and CEO changes after 1 year (/2years/ 3years ) after the IPO, respectively. In Panel A, for firm IPO performance measure, there are significant differences in mean and median BHAR 3years between non-turnover group and CEO-turnover group for the sample of CEO changes within five and within three years, respectively, following the IPO issuing since all $p$-values equals to zero. It is also consistent with the results shown in Panel B Table 5. However, there is no difference in mean and median LogIR between non-turnover group and CEO-turnover group for the same two sample datasets, since all $p$-values are greater than 0.1 .

\section{Table 4}

\begin{tabular}{|c|c|c|c|c|c|c|c|c|c|c|}
\hline \multicolumn{11}{|c|}{ Pearson Correlations between independent variables } \\
\hline & FirmBHAR3years & Founder & InMVt & LogAge & ROAt & LogIR & LogCEOage & Female & CEOtenure & CEOmba \\
\hline FirmBHAR3years & 1 & & & & & & & & & \\
\hline Founder & -0.026 & 1 & & & & & & & & \\
\hline InMVt & 0.051 & 0.013 & 1 & & & & & & & \\
\hline LogAge & -0.036 & -0.321 & $0.102^{*}$ & 1 & & & & & & \\
\hline ROAt & 0.034 & -0.143 & $0.277^{*}$ & $0.229^{*}$ & 1 & & & & & \\
\hline LogIR & 0.043 & 0.095 & $0.380^{*}$ & -0.134 & $0.115^{*}$ & 1 & & & & \\
\hline LogCEOage & 0.076 & -0.234 & -0.052 & $0.242^{*}$ & 0.006 & -0.1 & 1 & & & \\
\hline Female & -0.023 & 0.03 & -0.039 & 0.003 & -0.042 & 0.018 & 0.047 & 1 & & \\
\hline CEOtenure & 0.064 & 0.377 & -0.037 & 0.052 & 0.048 & 0.039 & 0.036 & -0.013 & 1 & \\
\hline CEOmba & -0.029 & -0.156 & -0.033 & -0.037 & 0.043 & 0.072 & -0.005 & -0.064 & -0.083 & 1 \\
\hline
\end{tabular}

*denote statistical significance at the 0.1 level

For firm accounting performance measure, there is difference in mean and median ROAt between non-turnover group and CEO-turnover group for the sample of CEO changes within 5 years, however, the significance level is at $10 \%$; Furthermore, there is a significant difference for the sample of CEO changes within 3 years, the nonturnover sample has a larger mean and median return on asset in the IPO year, in contrast with CEO -turnover sample as indicated by their Pvalues, at $1 \%$ significance level. Besides, for other control variables, there are significant differences in mean and median for both LnMVt and CEOtenure between non-turnover group and CEO-turnover group for the identical sample datasets, respectively, as their P-values are lower than 0.05 , which indicate firm size is smaller and CEO tenure is shorter, on average (and medians) for the sample of CEO changes within five and three years following the IPO issuing.

As shown in Panel B Table 6, there are significant differences in mean and median LogIR, ROAt, firm size and CEO tenure, respectively, between non-turnover group and CEO-turnover group for the sample of CEO changes after 1 year following the IPOs. And these $p$-values suggest that for CEO-turnover group have a lower mean and median LogIR, ROAt, LnMVt (firm size) and CEOtenure. However, there are only significant differences in mean and median ROAt, LogAge, CEO tenure, respectively, between non-turnover group and CEO-turnover group for the sample of CEO changes after 2 
years following the IPOs. And these p-values suggest that for CEO-turnover group have a lower mean and median ROAt, firm age and $C E$ Otenure.

Furthermore, LogIR is supposed to become a determining factor of CEO turnover event, only when it occurs 1 year following the IPOs, at 10\% significant level $(P$-value $=.029)$. And after comparing the $p$-values of differences in the mean and median ROAt shown for the first two samples in Panel $B$, there is a more significant difference for the sample of CEO changes after 2 years with regard to the variable of accounting performance, at $1 \%$ significant level( $P$ value $=.009$ ). . However, there is no significant difference in any variables' mean and median for the sample of CEO changes after 3 years following the IPOs, since all p-values are greater than 0.1 .

Table 5 Panel A: Descriptive statistics for all variables This table reports the descriptive statistics for the whole sample (462 firms, consists of 173 CEO turnover events within 5years after the IPO offering) during the period between 2003 and 2013.

\begin{tabular}{llllll}
\hline Variable & Observations & Mean & Standard Deviation & Min & Max \\
\hline CEOchwithin5 & 462 & 0.375 & 0.485 & 0.000 & 1.000 \\
FirmBHAR3years & 462 & 0.058 & 1.099 & -1.510 & 8.689 \\
Founder & 462 & 0.349 & 0.477 & 0.000 & 1.000 \\
InMVt & 462 & 6.218 & 1.139 & 2.926 & 11.053 \\
LogAge & 462 & 1.143 & 0.344 & 0.477 & 2.220 \\
ROAt & 462 & -0.068 & 0.277 & -4.094 & 0.434 \\
LogIR & 462 & 0.055 & 0.076 & -0.152 & 0.342 \\
LogCEOage & 462 & 1.704 & 0.069 & 1.431 & 1.881 \\
Female & 462 & 0.030 & 0.172 & 0.000 & 1.000 \\
CEOtenure & 462 & 5.377 & 4.624 & -0.680 & 40.000 \\
CEOmba & 462 & 0.310 & 0.463 & 0.000 & 1.000 \\
\hline
\end{tabular}

Panel B: Descriptive statistics for CEO turnover and non CEO turnover within 5 years after the IPO This table reports the descriptive statistics for CEO turnover (173 firms) and non-CEO turnover (289 firms) within 5 years after the IPO issuing for the whole sample (462 firms) during the period between 2003 and 2013.

\begin{tabular}{lllllllll}
\hline \multicolumn{7}{c}{ CEOchwithin5=1 } \\
\hline Variable & $\mathrm{n}$ & Mean & S.D. & Min & .25 & Mdn & .75 & Max \\
Firmbhar3years & 173 & $-\mathbf{0 . 2 3}$ & 0.85 & -1.34 & -0.71 & -0.47 & 0.11 & 3.72 \\
Founder & 173 & 0.29 & 0.45 & 0.00 & 0.00 & 0.00 & 1.00 & 1.00 \\
LnMVt & 173 & $\mathbf{6 . 0 8}$ & 1.17 & 3.25 & 5.41 & 5.95 & 6.74 & 10.92 \\
LogAge & 173 & 1.16 & 0.36 & 0.48 & 0.90 & 1.08 & 1.34 & 2.11 \\
ROAt & 173 & $-\mathbf{0 . 0 9}$ & 0.37 & -4.09 & -0.14 & 0.00 & 0.05 & 0.27 \\
LogIR & 173 & 0.05 & 0.07 & -0.15 & 0.00 & 0.04 & 0.09 & 0.28 \\
LogCEOage & 173 & 1.72 & 0.07 & 1.49 & 1.68 & 1.72 & 1.76 & 1.88 \\
Female & 173 & 0.03 & 0.17 & 0.00 & 0.00 & 0.00 & 0.00 & 1.00 \\
CEOtenure & 173 & $\mathbf{4 . 6 9}$ & 4.04 & -0.68 & 1.97 & 3.90 & 6.21 & 23.00
\end{tabular}




\begin{tabular}{|c|c|c|c|c|c|c|c|c|}
\hline CEOmba & 173 & 0.32 & 0.47 & 0.00 & 0.00 & 0.00 & 1.00 & 1.00 \\
\hline \multicolumn{9}{|c|}{ CEOchwithin5=0 } \\
\hline & & & & & \multicolumn{3}{|c|}{-------- Quantiles --------- } & \\
\hline Variable & $\mathrm{n}$ & Mean & S.D. & Min & .25 & Mdn & .75 & Max \\
\hline Firmbhar3years & 289 & 0.23 & 1.20 & -1.51 & -0.52 & -0.12 & 0.64 & 8.69 \\
\hline Founder & 289 & 0.38 & 0.49 & 0.00 & 0.00 & 0.00 & 1.00 & 1.00 \\
\hline LnMVt & 289 & 6.30 & 1.12 & 2.93 & 5.59 & 6.28 & 6.88 & 11.05 \\
\hline LogAge & 289 & 1.13 & 0.34 & 0.48 & 0.90 & 1.04 & 1.28 & 2.22 \\
\hline ROAt & 289 & -0.05 & 0.20 & -1.13 & -0.11 & 0.01 & 0.06 & 0.43 \\
\hline LogIR & 289 & 0.06 & 0.08 & -0.11 & 0.00 & 0.04 & 0.10 & 0.34 \\
\hline LogCEOage & 289 & 1.69 & 0.07 & 1.43 & 1.65 & 1.69 & 1.74 & 1.86 \\
\hline Female & 289 & 0.03 & 0.17 & 0.00 & 0.00 & 0.00 & 0.00 & 1.00 \\
\hline CEOtenure & 289 & 5.79 & 4.90 & -0.19 & 2.25 & 4.93 & 8.00 & 40.00 \\
\hline CEOmba & 289 & 0.30 & 0.46 & 0.00 & 0.00 & 0.00 & 1.00 & 1.00 \\
\hline
\end{tabular}

Table 6 T-tests and Wilcoxon Ranksum tests are employed to examine whether or not the difference of means and medians are different from zero. Test of difference in mean and median between two samples of CEO unchanged and CEO changed within 5years (or within 3 years) OR after 1 year/ 2years/ 3years) following the IPO are based on t-tests and Wilcoxon Ranksum tests, they are documented in Panel $A$ and Panel $B$, respectively. $N$ denotes the number of observations.

\section{Panel A}

Firm and CEO char- CEO unchanged IPOs acteristics

$$
\text { N Mean Median N Mean }
$$

CEO changes within 5 years following the IPO

$\begin{array}{lllllllll}\text { BHAR3years } & 289 & 0.23 & -0.12 & 173 & -0.23 & -0.47 & 0.000 & 0.000 \\ \text { LogIR } & 289 & 0.06 & 0.04 & 173 & 0.05 & 0.04 & 0.118 & 0.812 \\ \text { ROAt } & 289 & -0.05 & 0.01 & 173 & -0.09 & 0.05 & 0.097 & 0.500 \\ \text { LnMVt } & 289 & 6.31 & 6.28 & 173 & 6.08 & 5.95 & 0.020 & 0.025 \\ \text { LogAge } & 289 & 1.13 & 1.04 & 173 & 1.16 & 1.08 & 0.812 & 0.411 \\ \text { LogCEOage } & 289 & 1.69 & 1.69 & 173 & 1.72 & 1.72 & 0.999 & 0.000 \\ \text { CEOtenure } & 289 & 5.79 & 4.93 & 173 & 4.69 & 3.90 & 0.007 & 0.013\end{array}$

CEO changes within 3 years following the IPO

\begin{tabular}{|c|c|c|c|c|c|c|c|}
\hline BHAR3years & 343 & 0.18 & -0.14 & 119 & -0.29 & -0.56 & 0.000 \\
\hline LogIR & 343 & 0.06 & 0.04 & 119 & 0.05 & 0.04 & 0.399 \\
\hline ROAt & 343 & -0.05 & 0.02 & 119 & -0.12 & -0.01 & 0.009 \\
\hline LnMVt & 343 & 6.27 & 6.24 & 119 & 6.06 & 5.96 & 0.042 \\
\hline LogAge & 343 & 1.15 & 1.08 & 119 & 1.13 & 1.04 & 0.325 \\
\hline LogCEOage & 343 & 1.70 & 1.70 & 119 & 1.72 & 1.72 & 0.996 \\
\hline CEOtenure & 343 & 5.73 & 4.45 & 119 & 4.35 & 3.97 & 0.002 \\
\hline
\end{tabular}


Panel B

Firm and CEO charac- CEO unchanged IPOs teristics

N Mean Median N Mean

CEO changes after 1 year following the IPO

$\begin{array}{lcccc}\text { LogIR } & 441 & 0.06 & 0.04 & 21 \\ \text { ROAt } & 441 & -0.06 & 0.01 & 21 \\ \text { LnMVt } & 441 & 6.25 & 6.22 & 21 \\ \text { LogAge } & 441 & 1.14 & 1.04 & 21 \\ \text { LogCEOage } & 441 & 1.70 & 1.71 & 21 \\ \text { CEOtenure } & 441 & 5.49 & 4.37 & 21\end{array}$

CEO changes after 2 year following the IPO

$\begin{array}{lcccc}\text { LogIR } & 404 & 0.05 & 0.04 & 58 \\ \text { ROAt } & 404 & -0.06 & 0.01 & 58 \\ \text { LnMVt } & 404 & 6.23 & 6.21 & 58 \\ \text { LogAge } & 404 & 1.15 & 1.08 & 58 \\ \text { LogCEOage } & 404 & 1.70 & 1.71 & 58 \\ \text { CEOtenure } & 404 & 5.51 & 4.22 & 58\end{array}$

CEO changes after 3 year following the IPO

\begin{tabular}{lllllllll} 
LogIR & 422 & 0.05 & 0.04 & 40 & 0.06 & 0.05 & 0.653 & 0.314 \\
ROAt & 422 & -0.07 & 0.01 & 40 & -0.05 & 0.00 & 0.667 & 0.863 \\
LnMVt & 422 & 6.22 & 6.18 & 40 & 6.23 & 6.19 & 0.521 & 0.973 \\
LogAge & 422 & 1.14 & 1.04 & 40 & 1.19 & 1.13 & 0.791 & 0.518 \\
LogCEOage & 422 & 1.70 & 1.70 & 40 & 1.73 & 1.74 & 0.987 & 0.011 \\
CEOtenure & 422 & 5.42 & 4.22 & 40 & 4.90 & 4.23 & 0.250 & 0.889 \\
\hline
\end{tabular}

\subsection{Logit Regression Results}

Table 7 includes the results of logit estimation of the first two regression models employing both FirmBHAR3years as assess of IPO firms' performance in the previous years. It examines the relationship between IPO firms' performance in the long run and subsequent CEO turnover. The results show a significant negative correlation between CEO replaced both within 5 years or 3 years after the IPO and IPOs firm buy-and-hold stock return for three years holding period, since the coefficient estimates reported in Table 7 are negative. The results of the logit regression models reject the null hypothesis, and provide strong
CEO changed IPOs

21

21

21

21

21

21

58

0.02
-0.17
5.49
1.18
1.71
3.07

.

0.029

0.284

$-0.13$

0.038

0.041

5.56

0.001

0.005

1.15

0.690

0.397

1.72

0.607

0.590

2.73

0.010

0.008

Difference

ence in in median
mean

$\begin{array}{llll}0.06 & 0.04 & 0.697 & 0.510 \\ -0.15 & -0.01 & 0.009 & 0.112 \\ 6.15 & 6.05 & 0.326 & 0.585 \\ 1.08 & 0.98 & 0.055 & 0.054 \\ 1.72 & 1.72 & 0.918 & 0.165 \\ 4.42 & 4.20 & 0.046 & 0.458\end{array}$

510

112

.585

054

165

458

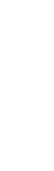


suggests that CEOtenure is negatively related to his/her turnover within 3 years after the IPO, at $5 \%$ significant level. Nevertheless, other variables controlled in these two regression models shown in Table 7, such as Founder, LnMVt,
LogAge, Female and CEOmba show no correlation with CEO turnover within 5 years or within 3 years following the IPO, at any specified significant level.

Table 7 This table reports the empirical results of examining whether the 3-year post-issue buy-andhold stock return can lead to CEO turnover within 5 years and within 3 years, respectively, after the IPO issuing. This logit regression controls for both CEO characteristics and firm characteristics that are supposed to be correlated with CEOchwithin5. The variables used for matching also include industry fixed effect with industry classification according to two-digit SIC codes, as well as year fixed effect, and consequently, the final sample in this logit regression consist of 438 and 435 observations, respectively, during the period between 2003 and 2013. Superscripts ***, **, * correspond to statistical significance at the 1,5 and 10 percent levels, respectively. The t- statistics and p-values are presented in parentheses and bracket, respectively, below coefficient estimates. Standard errors are adjusted for heteroscedasticity.

$C E O_{\text {chwithin } 5}=\beta_{0}+\beta_{1}$ PostIPO BHAR 3 years $+\beta_{2}$ CEO Founder $+\beta_{3} \ln M V_{t}+\beta_{4} \log A g e+\beta_{5} R_{\text {OA }}+\beta_{6}$ log $C E O_{\text {Age }}+\beta_{7} C E O_{\text {Female }}+\beta{ }_{8} C E O_{\text {Tenure }}+\beta 9 C E O_{M B A}+$ Industrydummies + Yeardummies $+\varepsilon$

CEO chwithin $3=\beta_{0}+\beta_{1}$ PostIPOBHAR3years $+\beta_{2} C E O_{\text {Founder }}+\beta_{3} \ln M V_{t}+\beta_{4} \log$ Age $+\beta_{5}$ ROA $_{t}+\beta_{6}$ log$C E O_{\text {Age }}+\beta_{7} C E O_{\text {Female }}+\beta_{8} C E O_{\text {Tenure }}+\beta 9 C E O_{M B A}+$ Industrydummies + Yeardummies $+\varepsilon$

\begin{tabular}{|c|c|c|}
\hline Dependent Variable & $\begin{array}{l}\text { CEO changes within } 5 \text { years following } \\
\text { the IPO issue }\end{array}$ & $\begin{array}{l}\text { CEO changes within } 3 \text { years following the } \\
\text { IPO issue }\end{array}$ \\
\hline Independent Variable & \multicolumn{2}{|c|}{ Outcome } \\
\hline BHAR3years & $\begin{array}{l}-0.494^{\star \star *} \\
(-3.32) \\
{[0.001]}\end{array}$ & $\begin{array}{l}-0.511^{\star \star \star} \\
(-2.60) \\
{[0.009]}\end{array}$ \\
\hline Founder & $\begin{array}{l}-0.162 \\
(-0.54) \\
{[0.589]}\end{array}$ & $\begin{array}{l}-0.215 \\
(-0.65) \\
{[0.515]}\end{array}$ \\
\hline LnMVt & $\begin{array}{l}-0.043 \\
(-0.34) \\
{[0.732]}\end{array}$ & $\begin{array}{l}-0.069 \\
(-0.52) \\
{[0.604]}\end{array}$ \\
\hline LogAge & $\begin{array}{l}-0.175 \\
(-0.44) \\
{[0.661]}\end{array}$ & $\begin{array}{l}-0.413 \\
(-0.95) \\
{[0.340]}\end{array}$ \\
\hline ROAt & $\begin{array}{l}-1.539^{\star *} \\
(-2.12) \\
{[0.034]}\end{array}$ & $\begin{array}{l}-1.752^{\star \star} \\
(-2.43) \\
{[0.015]}\end{array}$ \\
\hline LogCEOage & $\begin{array}{l}6.220^{* * *} \\
(3.03) \\
{[0.002]}\end{array}$ & $\begin{array}{l}5.604^{\star *} \\
(2.48) \\
{[0.013]}\end{array}$ \\
\hline Female & $\begin{array}{l}-0.146 \\
(-0.23) \\
{[0.816]}\end{array}$ & $\begin{array}{l}-1.084 \\
(-1.13) \\
{[0.259]}\end{array}$ \\
\hline CEOtenure & $\begin{array}{l}-0.036 \\
(-1.09)\end{array}$ & $\begin{array}{l}-0.072^{* *} \\
(-2.10)\end{array}$ \\
\hline
\end{tabular}




\begin{tabular}{lll}
\hline & {$[0.276]$} & {$[0.036]$} \\
CEOmba & 0.118 & 0.11 \\
& $(0.46)$ & $(0.40)$ \\
Intercept & {$[0.647]$} & {$[0.686]$} \\
& $-10.296^{* \star *}$ & $-9.824^{* \star *}$ \\
& $(-2.66)$ & $(-2.41)$ \\
Industry and Year Fixed Effect & {$[0.008]$} & {$[0.016]$} \\
Model Pseudo R square & 0.178 & YES \\
Number of observations & 438 & 0.167 \\
\hline
\end{tabular}

Table 8 As shown panel B in Table 6, there is a significant difference in the log of IPO initial return between CEO turnover group and CEO non-turnover group for the sample of CEO turnover 1 year after the IPO issued. This table reports the empirical results of examining whether or not the initial return on the IPO first trading day is correlated with CEOch1. The variables used for matching also include industry fixed effect with industry classification according to two-digit SIC codes, as well as year fixed effect. And the indicator variable of female coefficient result is zero in this test. Due to the industry and year fixed effect as well as the female variable omitted, consequently the final sample in this logit regression consists of 314 observations during the period between 2003 and 2013. Superscripts ${ }^{* * *},{ }^{* *},{ }^{*}$ correspond to statistical significance at the 1,5 and 10 percent levels, respectively. The t- statistics and $p$-values are presented in parentheses and bracket, respectively, below coefficient estimates. Standard errors are adjusted for heteroscedasticity.

$C E O_{\text {chwithin } 5}=\beta_{0}+\beta_{1} \log I R+\beta_{2} C E O_{\text {Founder }}+\beta_{3} \ln M V_{t}+\beta_{4} \log$ Age $+\beta_{5} R O A_{t}+\beta_{6} \log C E O_{A g e}+\beta_{7} C E O_{\text {Female }}$ $+\beta 8 C E O_{\text {Tenure }}+\beta 9 C E O_{M B A}+$ Industrydummies + Yeardummies $+\varepsilon$

$C E O_{\text {ch } 1}=\beta_{0}+\beta_{1} \log$ IR $+\beta_{2} C E O_{\text {Founder }}+\beta_{3} \ln M V_{t}+\beta_{4} \log$ Age $+\beta_{5} R O A_{t}+\beta_{6} \log C E O_{A g e}+\beta 7 C E O_{\text {Female }}$ $+\beta_{8} C E O_{\text {Tenure }}+\beta_{9} C E O_{M B A}+$ Industrydummies + Yeardummies $+\varepsilon$

\begin{tabular}{llc}
\hline Dependent Variable & $\begin{array}{l}\text { CEO changes within } 5 \text { years following } \\
\text { the IPO issue }\end{array}$ & $\begin{array}{l}\text { CEO changes after } \mathbf{1} \text { year following } \\
\text { the IPO issue }\end{array}$ \\
\hline Independent Variable & & Outcome \\
LogIR & -0.474 & -2.755 \\
& $(-0.28)$ & $(-0.86)$ \\
& {$[0.783]$} & {$[0.389]$} \\
Founder & -0.041 & -0.4723 \\
& $(-0.14)$ & $(-0.49)$ \\
LnMVt & {$[0.887]$} & {$[0.626]$} \\
& -0.408 & $-0.676^{* *}$ \\
& $(-0.31)$ & $(-2.37)$ \\
LogAge & {$[0.759]$} & {$[0.018]$} \\
& -0.182 & 1.056 \\
ROAt & $(-0.45)$ & $(-1.06)$ \\
& {$[0.651]$} & {$[0.288]$} \\
LogCEOage & $-1.487^{* *}$ & 0.107 \\
& $(-2.18)$ & -0.230 \\
& {$[0.029]$} & {$[0.816]$} \\
& $6.318^{* * *}$ & -1.025 \\
\hline
\end{tabular}




\begin{tabular}{lll}
\hline & $(-3.12)$ & $(-0.25)$ \\
CEOtenure & {$[0.002]$} & {$[0.802]$} \\
& -0.206 & $-0.2419^{* \star *}$ \\
& $(-0.34)$ & $(-2.70)$ \\
CEOmba & {$[0.736]$} & {$[0.007]$} \\
& -0.046 & 0.182 \\
& $(-1.45)$ & $(-0.31)$ \\
Intercept & {$[0.147]$} & {$[0.755]$} \\
& 0.173 & 4.359 \\
Industry and Year Fixed Effect & -0.68 & -0.560 \\
Model Pseudo R square & {$[0.494]$} & {$[0.573]$} \\
Number of observations & YES & YES \\
& 0.150 & 0.264 \\
\hline
\end{tabular}

Table 8 includes the results of logit estimation of the regression models using LogIR as measure of IPO firms' performance. It examines the relationship between IPO firms' performance in the short term and subsequent CEO turnover. The first main result of this table documents there is no association between CEO dismissed within 5 years and IPO firms' initial return on the first trading day. Furthermore, although in Panel B table 6 , which it suggests LogIR can be distinguished between the non-CEO turnover group and the CEO replaced group after 1 year following the IPO, the second main result of Table 8 represents that there is also no relationship between CEO turnover after one year following the IPO and initial return of IPO firms, at any specified significant level. These results provided a strong demonstration that there is no significant link between CEO replaced and IPO performance, which it is measured by initial return on the 1st trading day.

Besides, for accounting performance measure, the results provide evidence to support that there is also a significant association between CEO turnover within 5 years following the IPO and return on asset in the firm IPO year, respectively, at $5 \%$ significant level. However, there is no significant correlation between return on asset in the IPO year and CEO changes after one year following the IPO, since the $p$-value of this indicator (.816) approaches to 1, which it is not statistically significant.

Additionally, the results find that there is a significant positive relationship between CEO turnover within 5 years following the IPO and LogCEOage, at $1 \%$ significant level, which it is consistent with the results shown in Table 7; The result in Row (7) suggest that CEOtenure is negatively related to his/her turnover after one year following the IPO, at $1 \%$ significant level. Combined with the same indicator's result shown in Table 7, long CEO tenure is negatively related to his/ her turnover within 3 years after the IPO, particularly (significantly) related to his/ her turnover after one year following the IPO. The results show that $L n M V t$ (firm size) is negatively associated with CEO changes after one year following the IPO, at $1 \%$ significant level. However, other variables controlled in these two regression models as illustrated in Table 8 such as Founder, LogAge, Female and CEOmba show no correlation with CEO turnover within 5 years or after one year following the IPO, at any specified significant level.

Table 9 includes the results of logit estimation of the additionally regression models adopting ROAt as evaluation of IPO firms accounting performance in the IPO year. This table illustrates that CEO turnover after two years following the IPO launching is negatively correlated to the return on asset in the IPO year, at $5 \%$ significant 
level. However, according to Table 8 there is no significant relationship between CEO turnover after one year following the IPO issuing and return on asset in the IPO year, at any significant level. And this result is supposed to be result from the evidence shown in the first two samples in Panel B Table 6, ROAt has a larger significant difference the sample of CEO changes after 2 years. Combined with the results provided in the previous two tables, those results suggest there is statistically significant relationship between ROA in the IPO year and CEO turnover within 5 or 3 years after the IPO, specifically, after the two years following the IPO rather than in the IPO year.

Table 9 As shown panel B in Table 6, there is a significant difference in the ROAt between CEO turnover group and CEO non-turnover group for the sample of CEO turnover 2 year after the IPO issued. This table reports the empirical results of investigating whether return on asset (ROA in the IPO year, described as ROAt) can lead to CEO turnover after 2 year following the IPO issuing. This logit regression controls for both CEO characteristics and firm characteristics that are supposed to be correlated with CEOch2. The variables used for matching also include industry fixed effect with industry classification according to two-digit SIC codes, as well as year fixed effect and consequently the final sample in this logit regression consists of 388 observations during the period between 2003 and 2013. Superscripts ${ }^{* * *},{ }^{* *},{ }^{*}$ correspond to statistical significance at the 1,5 and 10 percent levels, respectively. The t- statistics and $p$-values are presented in parentheses and bracket, respectively, below coefficient estimates. Standard errors are adjusted for heteroscedasticity.

$C E O_{\text {ch } 2}=\beta_{0}+\beta_{1}$ ROA $_{t}+\beta_{2} C E O_{\text {Founder }}+\beta_{3} \ln M V_{t}+\beta_{4} \log$ Age $+\beta_{5} \log C E O_{\text {Age }}+\beta_{6} C E O_{\text {Female }}+\beta_{7}$ CE $O_{\text {Tenure }}+\beta_{8} C E O_{M B A}+$ Industrydummies + Yeardummies $+\varepsilon$

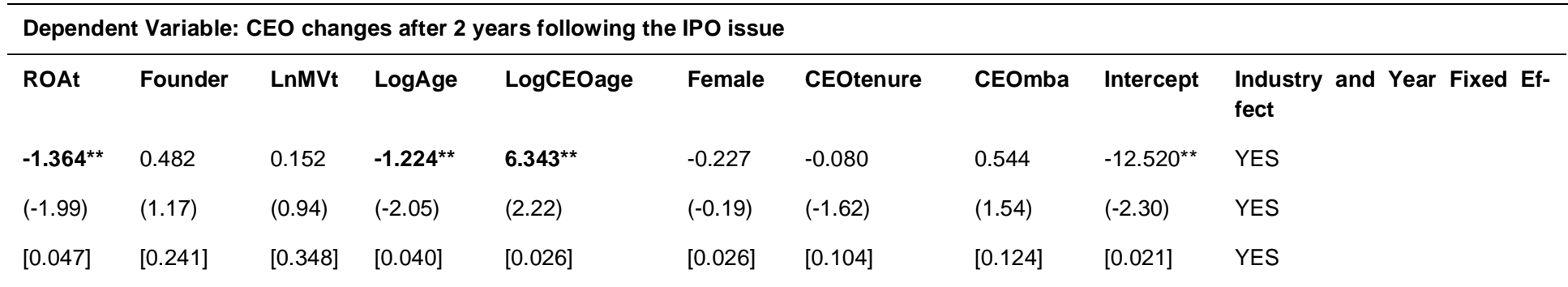

Model Pseudo R square: 0.176

\subsection{Empirical Results Discussion}

\subsubsection{IPO Performance \& Accounting Perfor- mance and CEO Turnover}

This study mainly provides strong empirical evidence to probe the usefulness of IPO long term underperformance is a key determinant of CEO departure decisions. They show firms CEO turnover within five or three years following the IPOs respond significantly to poor company performance as captured by IPOs firm buy-and-hold stock return for three years holding period, as described in Table 7, the result is consistent with prior evidences documented in the following, Coughlan and Schmidt (1985) who report that the stock price performance of firms is negatively related to the likelihood of a change in CEO position, Warner, Watts and Wruck (1988) who find that company with poor share return tend to replace their CEO, president as well as chairman, Murphy and Zimmerman (1993) and Kang and Shivdasani (1995) observe that bad performance forces CEO replaced decisions (disciplinary turnover) by the board. Furthermore, it confirms a similar empirical result of Depperu, 
Fabrizi and Ghezzi (2013) who suggest that CEO replaced is negatively associated with post-IPO performance in Italia by employing the U.S. sample data in this research.

However, this study provides empirical evidence to support that there is no influence of IPO short term performance (initial return) on the matter of CEO replacement, this result correspond with (Chang and Wong (2009) who document that there is no correlation between CEO turnover and the performance of firms which operate profitably. Furthermore, Ritter and Welch (2002) and Lowry, Officer and Schwert (2010) contend that the volatility of initial return fluctuates dramatically over time. It is therefore expected that CEO is not directly responsible for the extraordinary IPO initial return with greatly changes over time.

The regression results also provide empirical evidence with regard to the usefulness of accounting measure in the question of CEO turnovers. ROA is widely employed in previous research that examined accounting ratios as documented by Harrison, Torres and Kukalis (1988) and Shen (2000). ROA in the IPO year is found to have negative association with turnovers within 5 (3) years following the IPO, as interpreted in the logit regression results of additional hypothesis testing. The negative correlation found is consistent with the previous literature which indicates that the firm performance could be reflected in the succeeding diminution of return on assets, and consequently, drives a CEO turnover Coughlan and Schmidt (1985). Furthermore, there is a statistically significant correlation between ROA in the IPO year and CEO turnover after two years following the IPO as shown in Table 9, suggesting that CEO replacement decisions tend to be affected by historical performance rather than by contemporaneous company performance.

The results of this study discussed above can be consistent with the literature from different perspectives. When the firms' directors appoint a nominee for CEOs, the main concerns shall be their business experience and professional education background that could make contributions to firm performance and maximum the benefits of shareholders. Successor of a CEO can promote the firm value (powerful CEO turnover effect); and consequently, CEO turnover rate can be higher when the firm performs poorly, as documented by Helmich (1974) and Furtado and Rozeff (1987). Besides, Grusky (1963) assert that if the CEO is replaced due to the firm poor performance, however, a new successor is supposed to have little experience with firms' business culture in general, consequently, the firm performance get worse aggravated by stressed and separate internal relations, which in turn such vicious circles drives the stock price declines, and consequently, CEO turnover rate continues to become higher due to the firm underperformance. The empirical results of this study suggest that CEO turnover can be negatively affected by the IPO firms long term underperformance and the weak ROA in the IPO year can be explained by those arguments, and the empirical study conducted by Beatty and Zajac (1987) is consistent with Grusky (1963).

\subsubsection{CEO and Firm Characteristics \& CEO Turnover}

The regression result suggests that CEO turnover within 5 (3) years following the IPO is positively related to CEO age in U.S., which it is consistent with Murphy and Zimmerman (1993), Weisbach (1988) and Gibbons and Murphy (1990), who contend that there is a strong relation between CEO turnover and CEO age. This result indicates that IPO listed firms in U.S. are likely to employ young CEOs rather than aged CEOs on a board in order to enhance the effectiveness of the objectives implementation in the long run, while aged CEOs tend to be dismissed or changed to another positions such as chairman to improve the capacity of management CEO as well as the function of consultant. Nevertheless, shareholders may establish a retirement policy in place for the purpose of replacing the elderly and less competitive CEOs, and mandatory retirement polices is an additional reason for proving the age-turnover relation nonlinear, CEO age approximately 65 tend to normal 
retirement (non-disciplinary turnover), as documented by Goyal and Park (2002). And the finding of this study with regard to CEO age is totally different with the empirical results documented by Firth, Fung and Rui (2006), who suggest that CEO age has no association with turnover by investigating CEO departures in China. Furthermore, it has an inverse finding with the empirical research conducted by Jensen and Murphy (1990).

CEO tenure can be regarded as a proxy for management entrenchment; it is similar with CEO ownership. It seems to be concluded that if the CEO has more abilities and power, it would be less sensitivity exists in the association between CEO dismissals and firm performance as contended by Horner (2010). Evidence obtained from this study by employing US data sample show that CEO tenure is negatively related the likelihood of CEO turnover within three years after the IPO issuing. This evidence suggests that the boards have a lower probability of disciplining the CEOs for bad performance since boards with longer tenure CEOs have got trapped in the mind-set that CEO can be irreplaceable. This empirical result is supported by Salancik and Meindl (1984), who contend that CEOs with longer tenure could have built a power foundation over time, indicating that there is negatively association between CEO turnover and his tenure.

Firm size is negatively related to the CEO departure after one year following the IPO, it is consistent with Coles, Daniel and Naveen (2008), who contend that firm size is supposed to have ambiguous expected influence on the probability of CEO departure, CEOs at larger companies, ceteris paribus, and demand more complicated skill-sets, hence, they tend to more difficult to replace. Furthermore, it is in line with Offenberg (2009) to some degree, who document that there is no evidence that the likelihood of CEO turnover in small companies is greater than in large companies.

Other control variables in the area of CEO characteristics in this study did not receive any significant support. This study provides a contrary view with the previous empirical research for the control variable of Founder; it is contrast to the view as documented by Mitsuhashi and Welbourne (1999), who hypotheses that founder CEOs may have no experience in managing the firms which have approached to the IPO stage, and consequently, it is expected that going public is an additional chance for founder-CEOs to be assessed through external factors, founderCEOs tend to depart from the firm following the IPO issuing since there is a question of whether or not the founder-CEOs have enough ability to continue to direct the company to the post-IPO stage. This study provide the evidence to support that being the founder of the firm has no influence on CEO dismissals, this finding suggest a practical implication that if founder-CEOs lead the firm to the point of IPO stage, then they are supposed to have sufficient capacity to lead the company, arriving at the next moment of growth.

The results in this study regarding the variable of CEOmba is consistent with Huson, Parrino and Starks (2001) and Bhagat and Bolton (2008), it would not suggest $C E O$ education have a significant impact on whether or not a CEO will be replaced since the t-statistics of CEOmba variable is not statistically significant. CEO education appears to be not systematically related with CEO turnover, it has insignificant role on making the decisions to remove the current CEOs from their original position.

The influence of gender on CEO turnover has received relatively little research attention as argued by Hill, Upadhyay and Beekun (2014). In this study, there is no regression result show the significant relationship between the gender of CEO and CEO replacement. Lewis (1992) provide the empirical evidence to support the result of this study that there is no significant difference in turnover rates between male and female by investigating managers who worked for federal civil service in the U.S. Besides, this finding has an inverse perspective with the research investigating the frequency of female CEOs dismissal that conducted by Lyness and Judiesch (2001). 
And consequently, the gender bias will have no influence when making the decisions to change CEOs.

\section{Conclusion}

\subsection{Review of Findings}

This study is mainly conducted with the US sample data of 463 IPO firms including 173 (119) turnover events within 5 (3) years after the IPO issuing that happened during the period from 2003 to 2013. This study considers the firms that experienced firm performance-induced CEO turnover and examines the relationship between IPO performance and CEO turnover. This paper presents strong evidence to support that IPO long-term abnormal returns have a negative statistically significant influence on the occurrence of subsequent CEO turnovers within 5 (3) years after the IPO launching. However, for IPO shortterm initial return, it has no significant correlation with the CEO changes, even after one year following the IPO. The main highlight of this research provides a comparatively innovative area of the firm performance captured by IPO performance; it attracts little attention in the previous researches of their connections with CEO dismissals. The empirical results are, in concept, consistent with the reasons lead to CEO departures and are in accordance with the perspectives of the previous research achievements that firm financial performance can be regarded as the antecedent of CEO turnovers, as typically documented by Warner, Watts and Wruck (1988), Weisbach (1988) and Murphy and Zimmerman (1993). This study mainly concludes that CEO turnovers are affected by worsening phenomenon of the IPO abnormal underperformance in the long run, however, irrelevant to short-term initial return.

Besides, in terms of firm performance, this study contributes to the existing literature to investigate the association between accounting performance and CEO turnover by employing sample data of the recent years. And empirical results show that accounting performance captured as return on asset deteriorates prior to CEO turnover, and it is negatively associated with the subsequent CEO changes. It is consistent with the very representative researches conducted by Coughlan and Schmidt (1985) and Engel, Hayes and Wang (2003). Additionally, it explores what other factors (such as CEO age, tenure, education, founder status, gender, firm age, and firm size) influence the CEO changes. It is interesting to find aged CEO is likely to be replaced, which followed by Brickley (2003). However, the existence of mandatory retirement policy is a resistance force to support this linear correlation. It is also interesting to note that longer CEO tenure matters with respect to the reasons for turnover, and the CEOs of larger IPO firms are difficult to replace. While the reminders of CEO and firm characteristics deliberated in this research did not have any statistically significant influence on CEO turnovers.

\subsection{Managerial Implications}

The phenomenon of CEO turnover has become a topic that received much interest. Scholars, researchers and practitioners have paid a great amount attention on dealing with corporate governance issues. The increased probability of CEO turnover following the IPO in the long term as supported by the principle hypotheses of this study could encourage some companies to the decisions not to go public. CEOs as their perspectives, should take the choice of listing their companies into seriously consideration since it would impose a profound impact on their own position following the IPOs. Furthermore, CEO shall be responsible for the firm performance in the long run, rather than be responsible for the extraordinary return with greatly changes over time in the short run.

Besides, According to Kato and Long (2006), who considered CEO dismissals and its association with firm performance presents a crucial assessment of how efficiently a company can tackle with severe problems. First, make mediation between separate interests of CEOs and shareholders. Then, make the interests of major shareholders compatible with minor shareholders. It is therefore expected that the chances of CEO turnover can be lowered if CEOs have 
enough capacity to mediate these two major problems since they are essential components of being trusted. On the contrary, the failure of the CEO exacerbates IPO firm performance and subsequently the likelihood of a CEO turnover is greater as a result from shareholders or boards dissatisfaction with the performance of CEO. Hence, CEO turnover plays an important role in the developments of enterprises Chang and Wong (2009).

Additionally, it is consistent with the previous scholars, Engel, Hayes and Wang (2003) and Smith, Wright and Huo (2008), they indicate that when making important decisions, accounting information should take into serious account at the firm. Investigations on the variable ROA present it have significant association with CEO turnovers and it is in line with the findings documented by Shen (2000), who contend the importance of ROA and CEO turnover. Furthermore, ROA in the IPO year has a significant relationship with $\mathrm{CEO}$ departures after two years following the IPOs, rather than the IPO year, indicating an implication that CEO replacement decisions tend to be affected by historical performance rather than by contemporaneous company performance.

As the discussions above, the conclusion would be drawn to emphasize that IPO performance in the long run and historical accounting information can be regarded as crucial sources that to be deliberated when making important decisions with regard to the sustainability of executives' employment, such as CEO retention or termination.

\section{Reference}

1. Adams, John C., and Sattar A. Mansi, 2009, CEO turnover and bondholder wealth, Journal of Banking \& Finance 33, 522-533.

2. Adams, Renée, Heitor Almeida, and Daniel Ferreira, 2009, Understanding the relationship between founder-ceos and firm performance, Journal of Empirical Finance 16, 136-150.

3. Álvarez, Susana, and Víctor M. González, 2005, Signalling and the long-run performance of spanish initial public offerings (ipos), Journal of Business Finance \& Accounting 32, 325-350.
4. Anderson, Ronald C, and David M Reeb, 2003, Founding-family ownership and firm performance: Evidence from the s\&p 500, Journal of Finance 1301-1328.

5. Barber, Brad M, and John D Lyon, 1996, Detecting abnormal operating performance: The empirical power and specification of test statistics, Journal of Financial Economics 41, 359-399.

6. Barber, Brad M, and John D Lyon, 1997, Detecting long-run abnormal stock returns: The empirical power and specification of test statistics, Journal of Financial Economics 43, 341-372.

7. Baron, David P, 1982, A model of the demand for investment banking advising and distribution services for new issues, The Journal of Finance 955976.

8. Baron, David P., and Bengt Holmström, 1980, The investment banking contract for new issues under asymmetric information: Delegation and the incentive problem, The Journal of Finance 35, 1115-1138.

9. Barro, Jason R, and Robert J Barro, 1990, Pay, performance, and turnover of bank CEOs, (National Bureau of Economic Research).

10. Beatty, Randolph P, and Jay R Ritter, 1986, Investment banking, reputation, and the underpricing of initial public offerings, Journal of Financial Economics 15, 213-232.

11. Beatty, Randolph P, and Edward J Zajac, 1987, Ceo change and firm performance in large corporations: Succession effects and manager effects, Strategic Management Journal 8, 305-317.

12. Beatty, Randolph P, and Edward J Zajac, 1990, Top management incentives, monitoring, and riskbearing: A study of executive compensation, ownership, and board structure in initial public offerings, Academy of Management Proceedings (Academy of Management).

13. Benston, George J, 1985, The self-serving management hypothesis: Some evidence, Journal of Accounting and Economics 7, 67-84.

14. Bertrand, Marianne, and Antoinette Schoar, 2003, Managing with style: The effect of managers on firm policies, The Quarterly Journal of Economics 118, 1169-1208.

15. Bhagat, Sanjai, and Brian Bolton, 2008, Corporate governance and firm performance, Journal of Corporate Finance 14, 257-273.

16. Bhagat, Sanjai, Brian J Bolton, and Ajay Subramanian, 2010, Ceo education, ceo turnover, and firm performance, Available at SSRN 1670219.

17. Boeker, Warren, 1992, Power and managerial dismissal: Scapegoating at the top, Administrative Science Quarterly 400-421.

18. Borokhovich, Kenneth A, Robert Parrino, and Teresa Trapani, 1996, Outside directors and ceo 
selection, Journal of Financial and Quantitative Analysis 31, 337-355.

19. Brau, James C, Robert B Couch, and Ninon K Sutton, 2012, The desire to acquire and ipo long-run underperformance, Journal of Financial and Quantitative Analysis 47, 493-510.

20. Brickley, James A., 2003, Empirical research on ceo turnover and firm-performance: A discussion, Journal of Accounting and Economics 36, 227233.

21. Chaney, Paul K., and Craig M. Lewis, 1998, Income smoothing and underperformance in initial public offerings, Journal of Corporate Finance 4, 1-29.

22. Chang, Eric C., and Sonia M. L. Wong, 2009, Governance with multiple objectives: Evidence from top executive turnover in china, Journal of Corporate Finance 15, 230-244.

23. Coles, Jeffrey L, Naveen D Daniel, and Lalitha Naveen, 2008, Boards: Does one size fit all?, Journal of Financial Economics 87, 329-356.

24. Cosh, Andy, and Alan Hughes, 1997, Executive remuneration, executive dismissal and institutional shareholdings, International Journal of Industrial Organization 15, 469-492.

25. Coughlan, Anne T, and Ronald M Schmidt, 1985, Executive compensation, management turnover, and firm performance: An empirical investigation, Journal of Accounting and Economics 7, 43-66.

26. Coughlan, Anne T., and Ronald M. Schmidt, 1985, Executive compensation, management turnover, and firm performance: An empirical investigation, Journal of Accounting and Economics 7, 43-66.

27. Daily, Catherine M, S Trevis Certo, Dan R Dalton, and Rungpen Roengpitya, 2003, Ipo underpricing: A meta-analysis and research synthesis, Entrepreneurship Theory and Practice 27, 271-295.

28. Daily, Catherine M, Patricia P McDougall, Jeffrey G Covin, and Dan R Dalton, 2002, Governance and strategic leadership in entrepreneurial firms, Journal of Management 28, 387-412.

29. Daniel, Kent, David Hirshleifer, and Avanidhar Subrahmanyam, 1998, Investor psychology and security market under-and overreactions, The Journal of Finance 53, 1839-1885.

30. DeFond, Mark L, and Chul W Park, 1999, The effect of competition on CEO turnover, Journal of Accounting and Economics 27, 35-56.

31. Denis, David J, Diane K Denis, and Atulya Sarin, 1997, Ownership structure and top executive turnover, Journal of Financial Economics 45, 193-221.

32. Denis, David J, and Timothy A Kruse, 2000, Managerial discipline and corporate restructuring following performance declines, Journal of Financial Economics 55, 391-424.
33. Denis, David J., and Diane K. Denis, 1995, Performance changes following top management dismissals, The Journal of Finance 50, 1029-1057.

34. Depperu, Donatella, Enrico Fabrizi, and Daniele M Ghezzi, 2013, Ipo and ceo turnover. A study on italian companies listed, BANCARIA 9, 24-35.

35. Dikolli, ShaneS, WilliamJ Mayew, and Dhananjay Nanda, 2014, CEO tenure and the performanceturnover relation, Review of Accounting Studies 19, 281-327.

36. Engel, Ellen, Rachel M Hayes, and Xue Wang, 2003, Ceo turnover and properties of accounting information, Journal of Accounting and Economics 36, 197-226.

37. Faleye, Olubunmi, 2007, Classified boards, firm value, and managerial entrenchment, Journal of Financial Economics 83, 501-529.

38. Fama, Eugene F, 1998, Market efficiency, longterm returns, and behavioral finance, Journal of Financial Economics 49, 283-306.

39. Farrell, Kathleen A., and David A. Whidbee, 2002, Monitoring by the financial press and forced ceo turnover, Journal of Banking \& Finance 26, 22492276.

40. Fee, C Edward, and Charles J Hadlock, 2004, Management turnover across the corporate hierarchy, Journal of Accounting and Economics 37, 3-38.

41. Finkelstein, Sydney, 1992, Power in top management teams: Dimensions, measurement, and validation, The Academy of Management Journal 35, 505-538.

42. Firth, Michael, Peter MY Fung, and Oliver M Rui, 2006, Corporate performance and ceo compensation in china, Journal of Corporate Finance 12, 693-714.

43. Fisman, Raymond J, Rakesh Khurana, Matthew Rhodes-Kropf, and Soojin Yim, 2013, Governance and ceo turnover: Do something or do the right thing?, Management Science 60, 319-337.

44. Francoeur, Claude, Réal Labelle, and Bernard Sinclair-Desgagne, 2008, Gender diversity in corporate governance and top management, Journal of Business Ehics 81, 83-95.

45. Furtado, Eugene P. H., and Vijay Karan, 1990, Causes, consequences, and shareholder wealth effects of management turnover: A review of the empirical evidence, Financial Management 19, 60-75.

46. Furtado, Eugene PH, and Michael S Rozeff, 1987, The wealth effects of company initiated management changes, Journal of Financial Economics 18, 147-160.

47. Gao, Ning, and Bharat A. Jain, 2011, Founder ceo management and the long-run investment 
performance of ipo firms, Journal of Banking \& Finance 35, 1669-1682.

48. Gibbons, Robert, and Kevin J Murphy, 1990, Relative performance evaluation for chief executive officers, Industrial \& Labor Relations Review 43, 30S-51S.

49. Gompers, Paul A, and Josh Lerner, 2003, The really long-run performance of initial public offerings: The pre-nasdaq evidence, The Journal of Finance $58,1355-1392$.

50. Gounopoulos, Dimitrios, Christos Panagiotis Nounis, and Paris Stylianides, 2007, The short and long term performance of initial public offerings in the cyprus stock exchange, Journal of Financial Decision Making 4.

51. Goyal, Vidhan K, and Chul W Park, 2002, Board leadership structure and ceo turnover, Journal of Corporate Finance 8, 49-66.

52. Grusky, Oscar, 1963, Managerial succession and organizational effectiveness, American Journal of Sociology 21-31.

53. Harrison, J Richard, David L Torres, and Sal Kukalis, 1988, The changing of the guard: Turnover and structural change in the top-management positions, Administrative Science Quarterly 211232.

54. Harrison, J. Richard, David L. Torres, and Sal Kukalis, 1988, The changing of the guard: Turnover and structural change in the top-management positions, Administrative Science Quarterly 33, 211-232.

55. Helmich, Donald L, 1974, Organizational growth and succession patterns, Academy of Management Journal 17, 771-775.

56. Hermalin, Benjamin E, and Michael S Weisbach, 1988, The determinants of board composition, The RAND Journal of Economics 589-606.

57. Hill, Aaron D, Arun D Upadhyay, and Rafik I Beekun, 2014, Do female and ethnically diverse executives endure inequity in the ceo position or do they benefit from their minority status? An empirical examination, Strategic Management Journal.

58. Holmstrom, Bengt, 1992, Contracts and the market for executives: Comment, Contract economics 212-217.

59. Hölmstrom, Bengt, 1979, Moral hazard and observability, The Bell Journal of Economics 10, 7491.

60. Horner, Stephen V, 2010, Board power, CEO appointments and CEO duality, Academy of Strategic Management Journal 9, 43.

61. Hosmer Jr, David W, and Stanley Lemeshow, 2004. Applied logistic regression (John Wiley \& Sons).
62. Huson, Mark R, Robert Parrino, and Laura $T$ Starks, 2001, Internal monitoring mechanisms and ceo turnover: A long-term perspective, The Journal of Finance 56, 2265-2297.

63. Huson, Mark R., Paul H. Malatesta, and Robert Parrino, 2004, Managerial succession and firm performance, Journal of Financial Economics 74, 237-275.

64. Ibbotson, Roger G, 1975, Price performance of common stock new issues, Journal of Financial Economics 2, 235-272.

65. Jensen, Michael C, and Kevin J Murphy, 1990, Performance pay and top-management incentives, Journal of Political Economy 225-264.

66. Jenter, Dirk, and Fadi Kanaan, 2015, Ceo turnover and relative performance evaluation, The Journal of Finance.

67. Kang, Jun-Koo, and Anil Shivdasani, 1995, Firm performance, corporate governance, and top executive turnover in japan, Journal of Financial Economics 38, 29-58.

68. Kang, Jun-Koo, and Anil Shivdasani, 1996, Does the japanese governance system enhance shareholder wealth? Evidence from the stock-price effects of top management turnover, The Review of Financial Studies 9, 1061-1095.

69. Kato, Takao, and Cheryl Long, 2006, Executive turnover and firm performance in china, The American Economic Review 363-367.

70. Leone, Andrew J, and Michelle Liu, 2010, Accounting irregularities and executive turnover in founder-managed firms, The Accounting Review 85, 287-314.

71. Lewis, Jane, 1992, Gender and the development of welfare regimes, Journal of European Social Policy 2, 159-173.

72. Ljungqvist, Alexander, 2007, Ipo underpricing: A survey, handbook in corporate finance: Empirical corporate finance, Espen Eckbo, ed.

73. Loughran, Tim, and Jay R. Ritter, 1995, The new issues puzzle, The Journal of Finance 50, 23-51.

74. Lowry, Michelle, Micah S. Officer, and G. William Schwert, 2010, The variability of ipo initial returns, The Journal of Finance 65, 425-465.

75. Lyness, Karen S, and Michael K Judiesch, 2001, Are female managers quitters? The relationships of gender, promotions, and family leaves of absence to voluntary turnover, Journal of Applied Psychology 86, 1167.

76. Lyon, John D, Brad M Barber, and Chih-Ling Tsai, 1999, Improved methods for tests of long-run abnormal stock returns, The Journal of Finance 54, 165-201.

77. Mikkelson, Wayne H., and M. Megan Partch, 1997, The decline of takeovers and disciplinary 
managerial turnover, Journal of Financial Economics 44, 205-228.

78. Miller, Edward M., 1977, Risk, uncertainty, and divergence of opinion, The Journal of Finance 32, 1151-1168.

79. Mirrlees, James A., 1976, The optimal structure of incentives and authority within an organization, The Bell Journal of Economics 7, 105-131.

80. Mitchell, Mark L, and Erik Stafford, 2000, Managerial decisions and long-term stock price performance*, The Journal of Business 73, 287-329.

81. Mitsuhashi, Hitoshi, and Theresa M Welbourne, 1999, Chief executive officer (ceo) tenure in initial public offering (ipo) firms: An event history analysis of the determinants of turnover.

82. Morck, Randall, Andrei Shleifer, and Robert W. Vishny, 1989, Alternative mechanisms for corporate control, The American Economic Review 79, 842-852.

83. Murphy, Kevin J, and Jerold L Zimmerman, 1993, Financial performance surrounding ceo turnover, Journal of Accounting and Economics 16, 273315.

84. Offenberg, David, 2009, Firm size and the effectiveness of the market for corporate control, Journal of Corporate Finance 15, 66-79.

85. Osborn, Richard N., Lawrence R. Jauch, Thomas N. Martin, and William F. Glueck, 1981, The event of ceo succession, performance, and environmental conditions, The Academy of Management Journal 24, 183-191.

86. Pagano, Marco, Fabio Panetta, Zingales, and Luigi, 1998, Why do companies go public? An empirical analysis, The Journal of Finance 53, 27-64.

87. Pfeffer, Jeffrey, and William L Moore, 1980, Average tenure of academic department heads: The effects of paradigm, size, and departmental demography, Administrative Science Quarterly 387406.

88. Puffer, Sheila M, and Joseph B Weintrop, 1991, Corporate performance and ceo turnover: The role of performance expectations, Administrative Science Quarterly 1-19.

89. Rasbeed, AMA, Deepak K Datta, and Ravi $R$ Chinta, 1997, Determinants of price premiums: A study of initial public offerings in the medical diagnostics and devices industry, Journal of Small Business Management 35, 11-23.

90. Reilly, Frank K, and Kenneth Hatfield, 1969, Investor experience with new stock issues, Financial Analysts Journal 25, 73-80.

91. Ritter, Jay R, 1991, The long-run performance of initial public offerings, The lournal of Finance 46, 3-27.

92. Ritter, Jay R., 1984, The "hot issue" market of 1980, The Journal of Business 57, 215-240.
93. Ritter, Jay R., and Ivo Welch, 2002, A review of ipo activity, pricing, and allocations, The Journal of Finance 57, 1795-1828.

94. Rock, Kevin, 1986, Why new issues are underpriced, Journal of financial economics 15, 187212.

95. Rose, Caspar, 2007, Does female board representation influence firm performance? The danish evidence, Corporate Governance: An International Review 15, 404-413.

96. Rosen, Sherwin, 1990, Contracts and the market for executives, (National Bureau of Economic Research).

97. Salancik, Gerald R, and James R Meindl, 1984, Corporate attributions as strategic illusions of management control, Administrative science quarterly 238-254.

98. Salancik, Gerald R, and Jeffrey Pfeffer, 1980, Effects of ownership and performance on executive tenure in us corporations, Academy of Management journal 23, 653-664.

99. Schubert, Renate, Martin Brown, Matthias Gysler, and Hans Wolfgang Brachinger, 1999, Financial decision-making: Are women really more riskaverse?, American Economic Review 381-385.

100. Shavell, Steven, 1979, Risk sharing and incentives in the principal and agent relationship, The Bell Journal of Economics 10, 55-73.

101. Shen, Wei, 2000, Political dynamics within corporate upper echelons and their impacts on contender and outsider ceo successon, Academy of Management Proceedings BPS: H1.

102. Smith, Frank, Alan Wright, and $Y$ Paul Huo, 2008, Scapegoating only works if the herd is big: Downsizing, management turnover, and company turnaround, Journal of International Business Strategy 8.

103. Stelter, Nicole Z, 2002, Gender differences in leadership: Current social issues and future organizational implications, Journal of Leadership \& Organizational Studies 8, 88-99.

104. Stroh, Linda K, Jeanne M Brett, and Anne H Reilly, 1996, Family structure, glass ceiling, and traditional explanations for the differential rate of turnover of female and male managers, Journal of Vocational Behavior 49, 99-118.

105. Taylor, Lucian A, 2010, Why are ceos rarely fired? Evidence from structural estimation, The Journal of Finance 65, 2051-2087.

106. Teoh, Siew Hong, Ivo Welch, and Tak Jun Wong, 1998, Earnings management and the longrun market performance of initial public offerings, The Journal of Finance 53, 1935-1974.

107. Villalonga, Belen, and Raphael Amit, 2006, How do family ownership, control and 
management affect firm value?, Journal of Financial Economics 80, 385-417.

108. Virany, Beverly, Michael L Tushman, and Elaine Romanelli, 1985, A longitudinal study of the determinants and effects of executive succession, Academy of Management Proceedings (Academy of Management).

109. Warner, Jerold B., Ross L. Watts, and Karen $\mathrm{H}$. Wruck, 1988, Stock prices and top management changes, Journal of Financial Economics 20, 461-492.

110. Wasserman, Noam, 2003, Founder-ceo succession and the paradox of entrepreneurial success, Organization Science 14, 149-172.

111. Weisbach, Michael S., 1988, Outside directors and ceo turnover, Journal of Financial Economics 20, 431-460.

112. Welbourne, Theresa M, and Linda A Cyr, 1999, The human resource executive effect in initial public offering firms, Academy of Management Journal 42, 616-629. 